\title{
Serous Retinal Detachments Complicating Interferon-a and Ribavirin Treatment in Patients with Hepatitis C
}

\author{
Giulio Modorati Federico Di Matteo Elisabetta Miserocchi \\ Annalisa Colucci Francesco Bandello
}

Department of Ophthalmology, University Vita-Salute, Scientific Institute San

Raffaele, Milan, Italy

\section{Key Words}

Serous retinal detachment - Vogt-Koyanagi-Harada · Hepatitis C · Interferon · Uveitis

\begin{abstract}
Purpose: To report the cases of two patients with chronic hepatitis $C$ infection showing serous retinal detachments similar to Vogt-Koyanagi-Harada (VKH) disease.

Methods: We reviewed the clinical records of two patients who were diagnosed with VKH-like disease during combined interferon-a (IFNa) and ribavirin treatment.

Results: Interruption of IFNa and ribavirin treatment in association with oral corticosteroids resulted in a favorable visual outcome in the case of diffuse retinal detachment (case 1). On the contrary, visual acuity did not improve when late cicatricial stage disease was already present (case 2 ).

Conclusion: There is increasing evidence of a link between hepatitis $C$ virus infection treated with pegylated IFNa-2b and the development of $\mathrm{VKH}$-like disease. Knowing the potential side effects of IFNa and ribavirin administration is fundamentally important, as is the need to closely follow up those patients that need to undergo this treatment.
\end{abstract}

\section{Introduction}

Vogt-Koyanagi-Harada (VKH) disease, also known as uveomeningitic syndrome, is a rare idiopathic multisystem autoimmune granulomatous disorder affecting the eyes, meninges, auditory system and skin. The disease is thought to be due to an autoimmune Th1-mediated response to a melanocyte-associated antigen [1], but the initiation mechanism and development of the exact process remain poorly understood.

Recent reports suggest a link between hepatitis $\mathrm{C}$ virus (HCV) infection and/or its treatment and the development of bilateral uveitis that is virtually identical to VKH 
disease. We present two cases of VKH-like disease in patients treated with pegylated interferon- $\alpha$ (IFN $\alpha$ ) and ribavirin for chronic hepatitis C.

\section{Case Report}

\section{Case 1}

A 61-year-old woman contracted HCV in 2006 following a blood transfusion performed during a colectomy for adenocarcinoma. The patient's past medical history was relevant only for type I diabetes mellitus controlled with insulin therapy. Because of histological damage at liver biopsy, she was prescribed pegylated IFNa and ribavirin treatment from October 2006. After 3 months, the patient was referred to a hepatologist because of sudden vision loss in both eyes. The physician suspected an interferon-related side effect and immediately interrupted the treatment. Upon presentation at our Ocular Immunology and Uveitis Service, the patient's best-corrected visual acuity was hand motion in the right eye and 20/400 in the left eye. The anterior segment examination was normal and intraocular pressure was $10 \mathrm{~mm} \mathrm{Hg}$ in both eyes. The fundus examination showed diffuse bilateral serous retinal detachment (fig. 1). No auditory or neurological symptoms were noted, nor vitiligo, alopecia, or poliosis. Based on the revised diagnostic criteria for VKH we diagnosed 'probable' VKH disease and prescribed treatment with oral prednisone $25 \mathrm{mg} / \mathrm{die}$; the patient recovered to 20/25 in the right eye and to $20 / 20$ in the left eye.

Case 2

A 36-year-old man with HCV since 2004 was taking pegylated IFNa and ribavirin during the same period. He also suffered from celiac disease. After 6 months of treatment, he referred bilateral sudden vision loss to his ophthalmologist and was treated with $12.5 \mathrm{mg}$ oral prednisone per day without visual improvement. The patient was referred to our Ocular Immunology and Uveitis Service 15 months after the onset of initial symptoms for a second diagnostic and therapeutic opinion. At presentation, bestcorrected visual acuity was 20/200 in the right eye and 20/40 in the left eye. No neurological or auditory signs were noted, nor were vitiligo, poliosis or alopecia. The anterior segment revealed a marked posterior cortical cataract in the right eye and an initial posterior subcapsular cataract in the left eye. We noted bilateral nummular chorioretinal depigmented scars and retinal pigment epithelium clumping and migration compatible with late cicatricial stage probable VKH disease (fig. 2). Previous fluorescein angiograms showed multiple pinpoint hyperfluorescence at the level of the pigment epithelium and diffuse exudative retinal detachments in both eyes. Despite discontinuation of IFNa and ribavirin visual acuity did not improve.

\section{Discussion}

A causal effect between IFNa treatment for HCV infection and VKH disease has not yet been proven. The exact etiology of VKH itself remains unclear. VKH syndrome is possibly caused by a $\mathrm{T}$ cell-mediated autoimmune reaction against proteins related with choroidal melanocytes. The fact that the disease prevalence varies considerably among populations and that it commonly affects people with more pigmented skin and a certain HLA (human leukocyte antigen) predisposition highlights the importance of individual genetic predisposition for the development of VKH disease. However, the autoimmune reaction needs to be initiated by a triggering agent. Epstein-Barr or cytomegalovirus infections have been proposed as initiating factors. The infection may lead to the production of autoreactive antibodies through a process of molecular mimicry between viral and melanocyte-related antigens [1]. 
The immunogenicity of IFNa in ocular tissue has been known since 1997 when a possible role in the development of Behçet's disease, another autoimmune disorder in which T cell-mediated activation is thought to play a major role, was suggested. Furthermore, interferon and ribavirin can induce a Th1 response and modify the expression of MHC class II antigens, both of which are associated with the development of VKH disease. Therefore, despite the lack of evidence of a causal effect, IFNa and ribavirin might be involved in both the initiation of the autoimmune process and the induction of a higher susceptibility in developing VKH syndrome. The association between VKH-like syndrome and interferon treatment for hepatitis $\mathrm{C}$ was first suggested in 2003 [2]. Since then, seven other cases of HCV-positive patients presenting a VKH-like disease after IFNa treatment have been reported in the literature [3-5]. Most of the reported cases (table 1) show signs of systemic involvement such as skin lesions, auditory or neurologic symptoms in association with serous retinal detachment, which is one of the hallmarks of VKH disease. Nevertheless, our cases highlight the importance of including serous retinal detachment without systemic signs in suspecting VKH-like disease in patients under IFNa and ribavirin treatment for hepatitis C.

Despite the widespread use of interferon and ribavirin for the treatment of hepatitis $\mathrm{C}$, the small number of published cases of VKH-like disease following IFNa treatment shows that ocular immunological side effects are rare. However, IFNa may cause other more common significant side effects, including retinal vascular disorders, ischemic optic neuropathies, neovascular glaucoma and 'specific IFNa-related retinopathy,' i.e. retinopathy characterized by retinal hemorrhages, microaneurysms, and cotton-wool spots.

The presented cases emphasize the importance of early recognition and prompt adequate ophthalmological therapy in the presence of a VKH-like disease associated with IFN treatment. Discontinuation of IFN and ribavirin treatment in association with oral corticosteroids might result in a favorable visual outcome in the case of diffuse retinal detachment (case 1). Conversely, visual recovery is usually poor when late cicatricial stage disease is already present (case 2). If not promptly recognized, IFNa-related effects may lead to chronic bilateral severe vision loss. Therefore, it is of fundamental importance to recognize the potential side effects of IFNa and ribavirin administration, and to closely follow up patients if treatment needs to be continued.

\section{Acknowledgement}

The authors wish to thank Michael John, Professor of Applied English at the Vita-Salute San Raffaele University, for the English language editing of this manuscript.

\section{Disclosure Statement}

None of the authors has any financial interests concerning procedures nor drugs cited in this manuscript. 


\begin{tabular}{l|l|l|l} 
Case Reports in & $\begin{array}{l}\text { Case Rep Ophthalmol 2011;2:105-110 } \\
\text { DOl: 10.1159/000326747 }\end{array}$ & $\begin{array}{l}\text { Published online: } \\
\text { March 12, 2011 }\end{array}$ & $\begin{array}{l}\text { ○ 2011 S. Karger AG, Basel } \\
\text { ISSN 1663-2699 } \\
\text { www.karger.com/cop }\end{array}$ \\
\hline
\end{tabular}

Table 1. Comparison with previously reported cases of VKH-like disease associated with IFN treatment

\begin{tabular}{|c|c|c|c|c|c|c|c|c|}
\hline $\begin{array}{l}\text { Case } \\
\text { No. [ref.] }\end{array}$ & Origin & Age & Sex & $\begin{array}{l}\text { VA at } \\
\text { presentation }\end{array}$ & Anterior segment & Posterior segment & $\begin{array}{l}\text { Systemic } \\
\text { involvement }\end{array}$ & $\begin{array}{l}\text { VA at } \\
\text { follow-up }\end{array}$ \\
\hline $1[2]$ & Latino & 52 & $\mathrm{~F}$ & $<20 / 200$ & posterior synechiae & $\begin{array}{l}\text { vitritis, choroidal and scleral } \\
\text { thickening (echography) }\end{array}$ & $\mathrm{AL}, \mathrm{AU}$ & $\mathrm{HM}$ \\
\hline $2[3]$ & Asian & 36 & M & NR & NR & $\begin{array}{l}\text { serous retinal detachment, optic } \\
\text { disk swelling }\end{array}$ & $\mathrm{HE}$ & $20 / 20$ \\
\hline $3[4]$ & Mediterranean & 38 & $\mathrm{~F}$ & $\begin{array}{l}20 / 80 \text { OD } \\
20 / 200 \text { OS }\end{array}$ & $\begin{array}{l}\text { mild anterior chamber } \\
\text { reaction }\end{array}$ & $\begin{array}{l}\text { serous retinal detachment, optic } \\
\text { disk swelling }\end{array}$ & $\mathrm{HE}, \mathrm{AU}, \mathrm{ME}$ & $\begin{array}{l}20 / 20 \text { and } \\
20 / 20\end{array}$ \\
\hline $4[5]$ & Northern Europe & 42 & M & $\begin{array}{l}20 / 25 \text { OD } \\
20 / 40 \text { OS }\end{array}$ & normal & $\begin{array}{l}\text { serous retinal detachment, } \\
\text { choroidal folds, hyperemic optic } \\
\text { disk }\end{array}$ & VI, HE, PL & $\begin{array}{l}20 / 20 \text { both } \\
\text { eyes }\end{array}$ \\
\hline $5[5]$ & Northern Europe & 43 & $\mathrm{~F}$ & $\begin{array}{l}\text { 20/200 OD } \\
20 / 40 \text { OS }\end{array}$ & $\begin{array}{l}\text { bilateral keratic } \\
\text { precipitates; } 1+\text { cells } \\
\text { and flare }\end{array}$ & serous retinal detachment & PO, VI, HE & $\begin{array}{l}20 / 20 \text { both } \\
\text { eyes }\end{array}$ \\
\hline $6[5]$ & Mediterranean & 37 & M & $\begin{array}{l}20 / 200 \text { OD } \\
\text { HM OS }\end{array}$ & normal & $\begin{array}{l}\text { serous retinal detachment, optic } \\
\text { disk swelling, vitritis }\end{array}$ & PO, HE, AU, PL & $\begin{array}{l}\text { 20/20 OD, } \\
20 / 400 \text { OS }\end{array}$ \\
\hline 7 [5] & Northern Europe & 52 & $\mathrm{~F}$ & $\begin{array}{l}\text { 20/200 OD } \\
20 / 40 \text { OS }\end{array}$ & normal & $\begin{array}{l}\text { serous retinal detachment, } \\
\text { hyperemic optic disk }\end{array}$ & $\mathrm{AL}, \mathrm{AU}$ & $\begin{array}{l}20 / 20 \text { both } \\
\text { eyes }\end{array}$ \\
\hline 8 & Mediterranean & 61 & $\mathrm{~F}$ & $\begin{array}{l}\text { HM OD, } \\
20 / 400 \text { OS }\end{array}$ & normal & serous retinal detachment & none & $\begin{array}{l}\text { 20/25 OD } \\
20 / 20 \text { OS }\end{array}$ \\
\hline 9 & Mediterranean & 36 & M & $\begin{array}{l}20 / 200 \text { OD } \\
20 / 40 \text { OS }\end{array}$ & $\begin{array}{l}\text { posterior cortical } \\
\text { cataract (OD), } \\
\text { posterior subcapsular } \\
\text { cataract (OS) }\end{array}$ & $\begin{array}{l}\text { chorioretinal scars and retinal } \\
\text { pigment epithelium clumping }\end{array}$ & none & $\begin{array}{l}\text { 20/200 OD } \\
20 / 40 \text { OS }\end{array}$ \\
\hline
\end{tabular}

Cases 8 and 9 are from the present paper. $\mathrm{VA}=$ Visual acuity; $\mathrm{NR}=$ not reported; $\mathrm{VI}=$ vitiligo; $\mathrm{PO}=$ poliosis; $\mathrm{AL}=$ alopecia; $\mathrm{HE}=$ headache; $\mathrm{ME}=$ meningism; $\mathrm{AU}=$ auditory symptoms; $\mathrm{PL}=$ pleoxytosis; $\mathrm{HM}=$ hand motion; $\mathrm{OD}=$ right eye; $\mathrm{OS}=$ left eye. 


\begin{tabular}{c|l|l|l}
$\begin{array}{c}\text { Case Reports in } \\
\text { Ophthalinology }\end{array}$ & $\begin{array}{l}\text { Case Rep Ophthalmol 2011;2:105-110 } \\
\text { DOI: 10.1159/000326747 }\end{array}$ & $\begin{array}{l}\text { Published online: } \\
\text { March 12, 2011 }\end{array}$ & $\begin{array}{l}\text { O 2011 S. Karger AG, Basel } \\
\text { ISSN 1663-2699 } \\
\text { www.karger.com/cop }\end{array}$ \\
\hline
\end{tabular}



Fig. 1. Fundus photography evidencing diffuse serous retinal detachment (left eye).

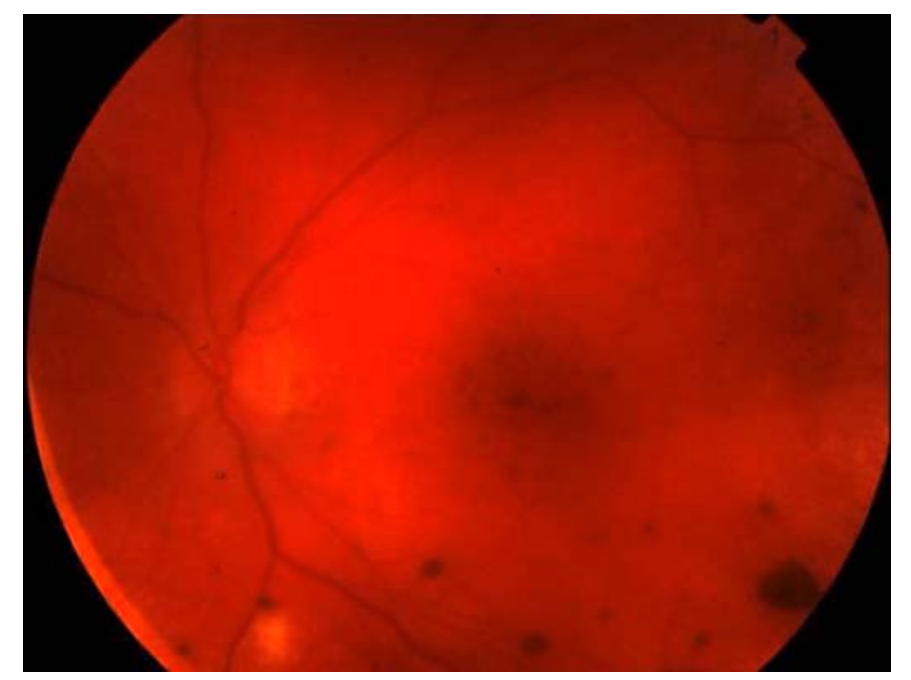

Fig. 2. Posterior pole photography evidencing depigmented scars and retinal pigment epithelium clumping (left eye). 


\section{References}

1 Fang W, Yang P: Vogt-Koyanagi-Harada syndrome. Curr Eye Res 2008;33:517-523.

2 Sylvestre DL, Disston AR, Bui DP: Vogt-Koyanagi-Harada disease associated with interferon alpha2b/ribavirin combination therapy. J Viral Hepat 2003;10:467-470.

-3 Kasahara A, Hiraide A, Tomita N, et al: Vogt-Koyanagi-Harada disease occurring during interferon alpha therapy for chronic hepatitis C. J Gastroenterol 2004;39:1106-1109.

4 Papastathopoulos K, Bouzas E, Naoum G, Vergados I, Tsiodras S: Vogt-Koyanagi-Harada disease associated with interferon-A and ribavirin therapy for chronic hepatitis C infection. J Infect 2006;52:59-61.

5 Touitou V, Bodaghi B, Cassoux N, et al: Vogt-Koyanagi-Harada disease in patients with chronic hepatitis C. Am J Ophthalmol 2005;140:949-952. 